УДК 330.341 DOI: https://doi.org/10.30977/PPВ.2226-8820.2021.27.60

JEL Classification: O33

\title{
ОСОБЛИВОСТІ ТА ТЕНДЕНЦІЇ ЦИФРОВОЇ ЕКОНОМІКИ В УКРАЇНІ
}

\author{
Дмитрісв I.А., доктор екон. наук, професор \\ Дмитрієва О.І., доктор екон. наук, доцент \\ Харківський національний автомобільно-дорожній університет
}

Постановка проблеми. Характерною ознакою сучасного етапу розвитку економіки $€$ використання цифрових технологій, які стали каталізатором різкого збільшення мобільності товарних та фінансових потоків, забезпечують високу швидкість передачі інформації, внесли значний вклад в глобалізаційні та інтеграційні процеси світової економіки. Інформаційні технології стали невід'ємною частиною суспільних відносин та призвели до появи нових галузей господарства, ринків, конкурентних товарів та послуг. Великий потенціал Інтернету став ключовим елементом економіки більшості держав. Все це вимагає від України адаптації до світових стандартів у сфері цифровізації. Тому визначення особливостей та тенденцій розвитку цифрової економіки України наразі є досить актуальним питанням.

Аналіз останніх досліджень і публікацій. Особливості і проблеми розвитку цифрової економіки в сучасних наукових дослідженнях $є$ дуже популярним питанням. Особливо вагомий внесок в дану проблематику внесли такі зарубіжні та вітчизняні вчені та дослідники , як В. Айзексон, С. Бранд, Дж. Вейлз, Е. Вільямс, Б. Гейтс, Б. Елбрехт, Д. Енгельбарт, Дж. Ліклайдер, Дж. ФонНейман, Е. Петерс, С. Хантінгтон, Д. Тапскот, М. В. Руденко, О. Марченко, Н. Ю. Подольчак, О.І. Білик та інші.

Термін «цифрова економіка» було запропоновано бізнес-аналітиком Дон Тапскотом. В своєму дослідженні автор характеризує цифрову економіку як економічну діяльність, яка визначається через мережеву свідомість та залежить від віртуальних технологій [1].

В дослідженні [2] автори визнають цифрову економіку як різновид ринку суб'єктів економічної системи на якому один, декілька або всі етапи господарських процесів здійснюються через комп'ютерні мережі; один із проявів економічної свободи, інноваційності та рівня розвитку економіки.

Руденко М.В. [3] окреслює наступні компоненти цифрової економіки, які необхідні для іiі ефективного функціонування: інформаційні та телекомунікаційні технології; людський капітал; сприятливий бізнес-клімат, ефективне управління. У своєму дослідженні науковець зазначає, що фундаментом цифрової економіки $є$ розвинена та ефективно функціонуюча цифрова інфраструктура.

Марченко О. [4] у своєму дослідженні робить висновок, що цифрова економіка $\epsilon$ доповненням до традиційної економіки, що передбачає 
виготовлення та реалізацію традиційних товарів і послуг із використанням комп’ютерного обладнання та цифрових систем, зокрема мережі Інтернет.

Таким чином, можна зазначити, що більшість авторів зводяться до визначення цифрової економіки як господарської діяльності (виробництво, продаж, постачання продукті, надання послуг тощо) за допомогою інформаційно-комунікаційних мереж.

В Концепції розвитку цифрової економіки та суспільства України на 2018-2020 рр. зазначено, що «цифрова економіка» - це діяльність, в якій основними засобами (факторами) виробництва $\epsilon$ цифрові (електронні, віртуальні) дані як числові, так і текстові. Цифрова економіка базується на інформаційно-комунікаційних та цифрових технологіях, стрімкий розвиток та поширення яких вже сьогодні впливають на традиційну (фізично-аналогову) економіку, трансформуючи їі від такої, що споживає ресурси, до економіки, що створює ресурси. [5].

Економічна стратегія «Україна 2030Е - країна з розвинутою цифровою економікою» визначає термін «цифрова економіка» наступним чином: «це тип економіки, де ключовими факторами (засобами) виробництва є цифрові дані: числові, текстові тощо. Їх використання як ресурсу дає змогу істотно підвищити ефективність, продуктивність, цінність послуг та товарів, побудувати цифрове суспільство» [6].

Невирішені складові загальної проблеми. Незважаючи на вагомий внесок у дослідження особливостей впровадження та розвитку цифрової економіки багатьох вчених, варто зауважити, що це питання залишається дискусійним, щодо якого в науковій спільноті немає єдності думок. Потребує більшого дослідження особливості та тенденції розвитку цифрової економіки України та ідентифікація чинної нормативно-правої бази.

Формулювання цілей статі. Метою статті $\epsilon$ вивчення основних тенденцій розвитку цифрової економіки України та ідентифікація чинного законодавчого підгрунтя.

Виклад основного матеріалу дослідження. Підтримуючи Проєкт цифрового перетворення економіки, що був представлений у 2015 p. на Всесвітньому економічному форумі, ряд держав на національному рівні почали реалізовувати стратегіі та концепції розвитку власної цифрової економіки. Деякі країни свої стратегічні напрями розвитку цифрової економіки реалізують на більш глобальному масштабі, а саме в національних стратегіях сталого розвитку чи програмах забезпечення конкурентоспроможності держави. Проєкт цифрового перетворення індустрії визначав шість важливих галузей економіки, таких як: товари народного споживання, електроенергетика, автомобілебудування, охорона здоров'я, засоби масової інформації, логістика. Протягом 2016-2017 pp. до цього проєкту приєдналися ще вісім галузей: страхування, авіація, готельна справа, професійні послуги та телекомунікації, видобуток нафти й газу, хімічна та гірничодобувна промисловість. Таким чином, 3 урахуванням стратегічних орієнтирів та особливостей галузей економіки, комісією ЄС була започаткована Стратегія єдиного ринку, що 
представляє собою дорожню карту щодо розкриття потенціалу єдиного цифрового ринку.

Україна також зацікавлена в інтеграції в єдиний європейський цифровий простір та підтримує цифрові перетворення економіки. Ключовим етапом інтеграції України в єдиний цифровий простір є розробка законодавчої бази розвитку цифрової економіки. Для цього в державі поступово впроваджується відповідна нормативно-правова база. Так, у 2016 році Міністерством економічного розвитку та торгівлі України за підтримки представників державних органів влади, прогресивних підприємств у сфері цифрових технологій, громадських організацій, консалтингових груп, науковців та незалежних експертів був представлений проєкт «Цифрова адженда України 2020» [7]. Цей проєкт передбачав вирішення наступних питань: цифрова модернізація усіх сфер життя та діяльності населення; трансформація традиційної економіки у конкурентоспроможну, ефективну та інвестиційнопривабливу; доступність цифрових технологій; підвищення економічних показників на міжнародному рівні; можливості для розвитку людських ресурсів, інноваційного підприємництва, цифрової індустрії [7]. Для вирішення зазначених питань у 2018 році урядом була затверджена Концепція розвитку цифрової економіки та суспільства на 2018-2020 рр., яка розкриває основну мету цифрового розвитку та напрями впровадження відповідних стимулів для цифровізації економіки, суспільної та соціальної сфер, усвідомлення наявних викликів та інструментів розвитку цифрових інфраструктур, набуття громадянами цифрових компетенцій, а також визначає критичні сфери та проєкти цифровізації, стимулювання внутрішнього ринку виробництва, використання та споживання цифрових технологій [5].

Для реалізації визначених цілей та напрямів розвитку цифрової економіки у 2019 році було створено Комітет з питань цифрової трансформації, на який покладено вирішення наступних завдань:

- формування законодавчої бази цифровізації та цифрового суспільства;

- розробка законодавчої бази адміністрування, функціонування i використання мережі Інтернет;

- розробка Національної та державної програмами інформатизації, а також програмами СС «Єдиний цифровий ринок»;

- розробка програм цифрового співробітництва;

- електронне урядування та публічні електронні послуги;

- смарт-інфраструктури;

- кібербезпека та кіберзахист.

В цьому ж році Кабінетом Міністрів України було реорганізовано Державне агентство з питань електронного урядування шляхом перетворення у Міністерство цифрової трансформації України, яке наразі $\epsilon$ центральним органом виконавчої влади 3 питань формування та реалізації державної політики у сфері цифровізації, цифрового розвитку, цифрової економіки, цифрових інновацій, електронного урядування та електронної демократії, розвитку інформаційного суспільства, розвитку IT-індустрії. 
Українським інститутом майбутнього в 2018 році була розроблена Економічна стратегія «Україна 2030Е - країна 3 розвинутою цифровою економікою». В запропонованій стратегії представлено сучасне бачення розвитку цифрової економіки країни та кроки для ії розвитку в Україні. Дана стратегія має дещо хаотичні твердження, що пов'язано з відсутністю чіткої цілісної системи положень, законів та підзаконних актів, що розкривають цілісне уявлення щодо розвитку цифрової економіки в галузях в сучасних умовах господарювання.

Таким чином, можна зробити висновок, що Україна поступово робить кроки щодо інтеграції в єдиний європейський цифровий простір, перш за все розробляючи необхідну нормативно-правову базу для забезпечення розвитку цифрової економіки держави.

Одним із важливих параметрів, які на світовому рівні визначають якість та ступінь розвитку цифрової економіки, $\epsilon$ світові рейтинги. Згідно 3 Концепцією розвитку цифрової економіки та суспільства України на 2018-2020 pp. основними рейтинговими цілями ії реалізації є досягнення у 2020 році [5]:

- 30 місця в рейтингу Networked Readiness Index (WEF) (у 2016 році - 64 місце);

- 40 місця у рейтингу Global Innovation Index (INSEAD, WIPO) (у 2016 році - 56 місце);

- 50 місця у рейтингу ICT Development Index (ITU) (у 2016 році - 79 місце); 85 місце).

- 60 місця у рейтингу Global Competitiveness Index (WEF) (у 2016 році -

Для аналізу особливостей та тенденцій розвитку цифрової економіки України необхідним $є$ дослідження рейтингових індексів, що дають змогу оцінити її стан. Найбільш поширеними індексами $\epsilon$ :

1. Індекс цифрової економіки та суспільства (Digital Economy and Society Index - DESI) - $є$ зведеним індексом, який узагальнює відповідні показники щодо ефективності цифрових технологій у Європі та відстежує еволюцію держав-членів $\mathrm{CC}$ у галузі цифрової конкурентоспроможності. Індекс DESI охоплює п'ять основних областей: зв'язок, людський капітал, використання Інтернету, інтеграцію цифрових технологій та цифрові державні послуги [8]. Але нажаль в нашій країні немає представництва, тому Україна в цьому рейтингу не представлена.

2. Індекс цифрової еволюції (Digital Evolution Index - DEI) - є основою рейтингу цифрового розвитку та конкурентоспроможності країни. Даний рейтинг враховує такі основні фактори: поточний рівень цифрового розвитку та темпи зростання оцифрувань. Для визначення рейтингу використовуються чотири субіндекси: рівень пропозиції, попит на цифрові технології, інституційне середовище, інноваційний клімат. Індекс цифрової еволюції також немає представництва в Україні, тому наша держава в рейтингу не представлена. 
3. Індекс прийняття цифровізації (Digital Adoption Index - DAI) - це всесвітній індекс, який вимірює впровадження цифрових технологій у трьох вимірах економіки: люди, уряд і бізнес. Індекс охоплює 180 країн за шкалою 01 i підкреслює «пропозицію» впровадження цифрових технологій, щоб максимізувати охоплення та спростити теоретичні зв'язки. Загальний $D A I \epsilon$ простим середнім 3 трьох субіндексів: підвищення продуктивності та прискорення широкого зростання бізнесу, розширення можливостей та покращення добробуту людей, підвищення ефективності та підзвітності надання послуг уряду [9]. В табл. 1. представлено позиції України в цьому рейтингу. Як бачимо за два роки Україна зміцнила свої позиції.

Таблиия 1

Позиції України у Digital Adoption Index - DAI

\begin{tabular}{|c|c|c|}
\hline Показник & $2014 \mathrm{p}$. & $2016 \mathrm{p}$. \\
\hline $\begin{array}{c}\text { Індекс прийнття цифровізації } \\
\text { DAI }\end{array}$ & 0,451108336 & 0,537763536 \\
\hline DAI Business & 0,605899632 & 0,667723715 \\
\hline DAI People & 0,382263 & 0,473988 \\
\hline DAI Government & 0,365163 & 0,471579 \\
\hline
\end{tabular}

Джерело: [9]

4. Індекс розвитку інформаційно-комунікаційних технологій (ICT Development Index) - це комбінований показник, який визначає досягнення країн світу щодо розвитку інформаційно-комунікаційних технологій (IКТ). Розраховується за методикою Міжнародного союзу електрозв'язку (International Telecommunication Union) [10]. В табл. 2. представлено позиції та ранг України в цьому рейтингу. Як бачимо за три роки в цьому рейтингу Україна також зміцнила свої позиції.

Таблиия 2

Позиції України у ICT Development Index

\begin{tabular}{|c|c|c|c|}
\hline Показник & $2014 \mathrm{p}$. & $2015 \mathrm{p}$. & $2017 \mathrm{p}$. \\
\hline ICT & 5,15 & 5,23 & 5,62 \\
\hline Ранг & 73 & 79 & 79 \\
\hline
\end{tabular}

Джерело: [10]

5. Глобальний інноваційний індекс (Global Innovation Index - GII) - один 3 найбільш популярів рейтингів країн 3 цифрової економіки. Цей щорічний рейтинг щодо здібності та успіхів в інноваціях. Він публікується Всесвітньою організацією інтелектуальної власності у співпраці 3 Корнельським університетом, INSEAD [11]. Цей рейтинг включає складові показники інноваційної сфери та об'єднує їх у два субіндекси: показники, що характеризують інноваційний потенціал країни (55 показників - Innovation Input Sub-index); показники, що характеризують наукові й творчі результати інноваційної діяльності (27 показників - Innovation Output Sub-index). В табл. 3 представлено позиції та ранг України. Як бачимо найкращі показники України 
в цьому рейтингу були представлені в 2018 р., але все одно просліджується тенденція до зміцнення позицій держави.

Таблиия 3

Позиції України у Global Innovation Index

\begin{tabular}{|c|c|c|c|c|c|c|}
\hline Показник & 2015 p. & 2016 p. & 2017 p. & 2018 p. & 2019 p. & 2020 p. \\
\hline GII & 36,45 & 35,72 & 37,62 & 38,52 & 37,40 & 36,32 \\
\hline $\begin{array}{c}\text { Місце в } \\
\text { рейтингу }\end{array}$ & 64 & 56 & 50 & 43 & 47 & 45 \\
\hline
\end{tabular}

Джерело: [11]

6. Індекс мережевої готовності (Networked Readiness Index - NRI) - це комплексний показник, що характеризує рівень розвитку інформаційнокомунікаційних технологій та мережевої економіки різних країн світу [12]. Цей індекс вважається одним 3 найважніших показників інноваційного та технологічного потенціалу країн світу та можливостей їх розвитку в сфері цифрової економіки. Він вимірюе ступінь розвитку інформаційнокомунікативних технологій держави за 62 показниками, які зведені в 4 основні групи: технології; люди; управління; вплив. На рис. 1 представлено динаміку позиції та місця України в цьому рейтингу, в якій можна прослідити зміцнення позицій держави за рік. Так як у 2019 році Індекс був грунтовно перероблений аналіз проведено тільки за два роки.

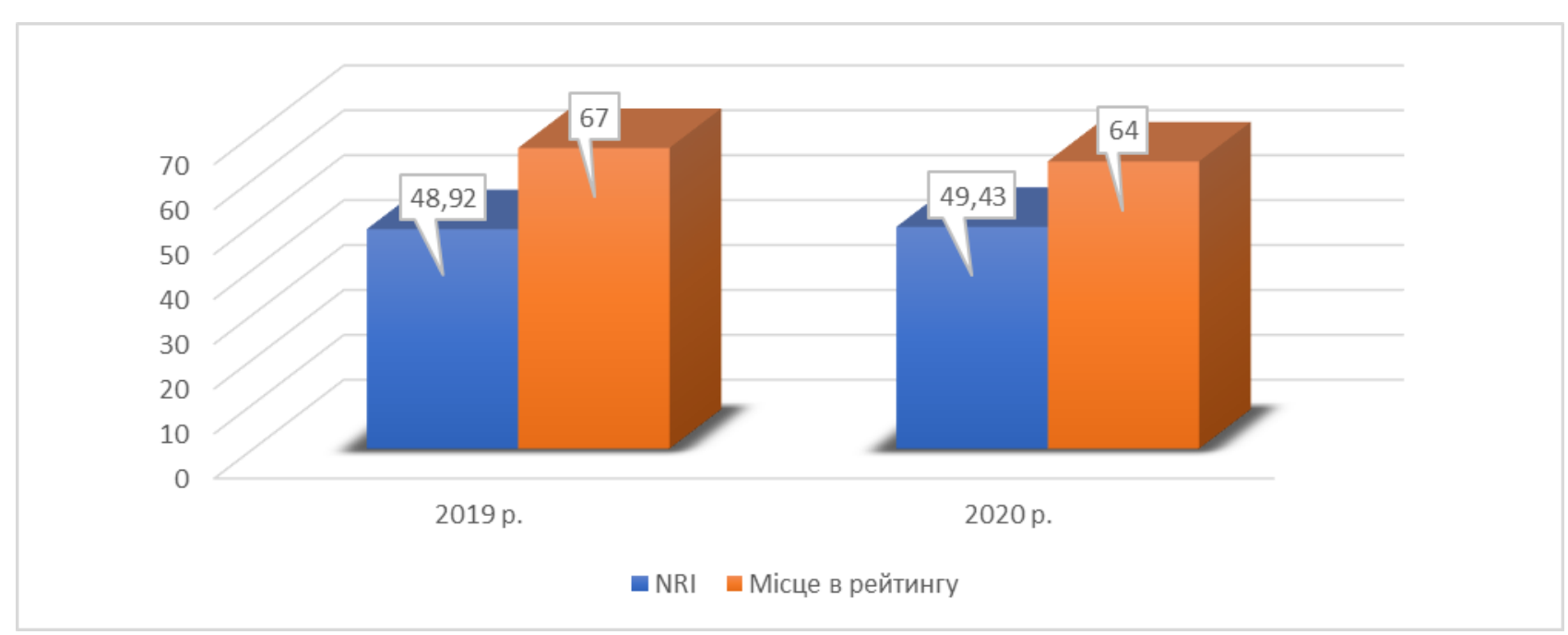

Рис. 1. Позиції України у Networked Readiness Index

Джерело: [12]

7. Індекс цифровізації економіки (Boston Consulting Group - e-Intensity) індекс включає 28 показників, які розраховується як середньозважена сума трьох субіндексів: розвиток інфраструктури, онлайн-витрати та активність користувачів [13]. В якості джерел інформації для формування рейтингів використовують наступні міжнародні звіти: звіт Gartner, Ovum, Pyramid Research, Euromonitor, звіт ООН о рівні розвитку електронного уряду (EGovernment survey), звіт Всесвітнього економічного форуму о ступені розвитку 
інформаційних технологій (The Global Information Technology Report). Положення України в даному рейтингу наведено на рис 2.

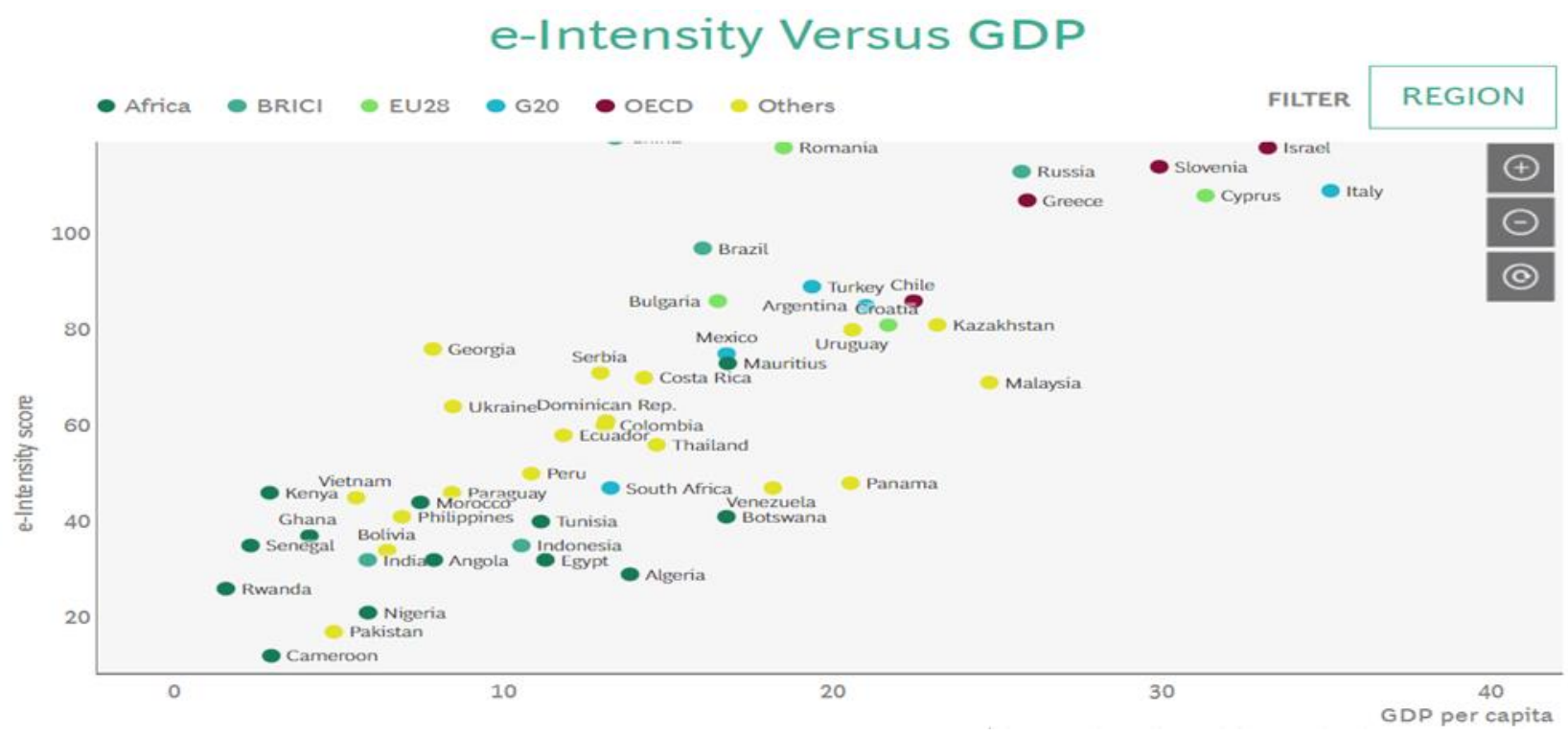

Рис. 2. Позиції України у рейтингу Boston Consulting Group

Джерело: [13]

8. Індекс світової цифрової конкурентоспроможності (IMD World Digital Competiveness Index - WDCI) - оцінює спроможність та готовність економіки держави впроваджувати та досліджувати цифрові технології як ключову рушійну силу економічних перетворень у бізнесі, уряді та суспільстві [14]. Цей індекс базується включає 50 показників, що згруповані в три субіндекси 1 рівня: знання, технології, майбутня готовність. Субіндекси першого рівня розкриваються субіндесами 2 рівня. По загальному рейтингу в 2018 р. за WDCI Україна знаходиться на 58 місці.

9. Global Competitiveness Index - GCI - рейтинг країн світу, за показником економічної конкурентоспроможності. Розрахований за методикою Всесвітнього економічного форуму, заснованій на зіставленні загальнодоступних статистичних даних і підсумків загального опитування керівників компаній - великого щорічного дослідження, яке проводиться ВЕФ разом 3 мережею партнерських організацій - провідних дослідницьких інститутів і організацій у країнах, аналізованих у звіті [15]. Цей індекс складається 3113 змінних, які визначають рівень конкурентоспроможності країни, всі змінні систематизовано до 12 ключових показників: якість інститутів; інфраструктура; макроекономічна стабільність; здоров'я і початкова освіта; вища освіта і професійна підготовка; ефективність на ринку товарів і послуг; ефективність на ринку праці; розвиненість фінансового ринку; рівень технологічного розвитку; розмір внутрішнього ринку; конкурентоспроможність компаній; інноваційний потенціал. На рис. 3 представлено динаміку місця України в цьому рейтингу, в якій можна прослідити погіршення позицій держави з кожним роком. 


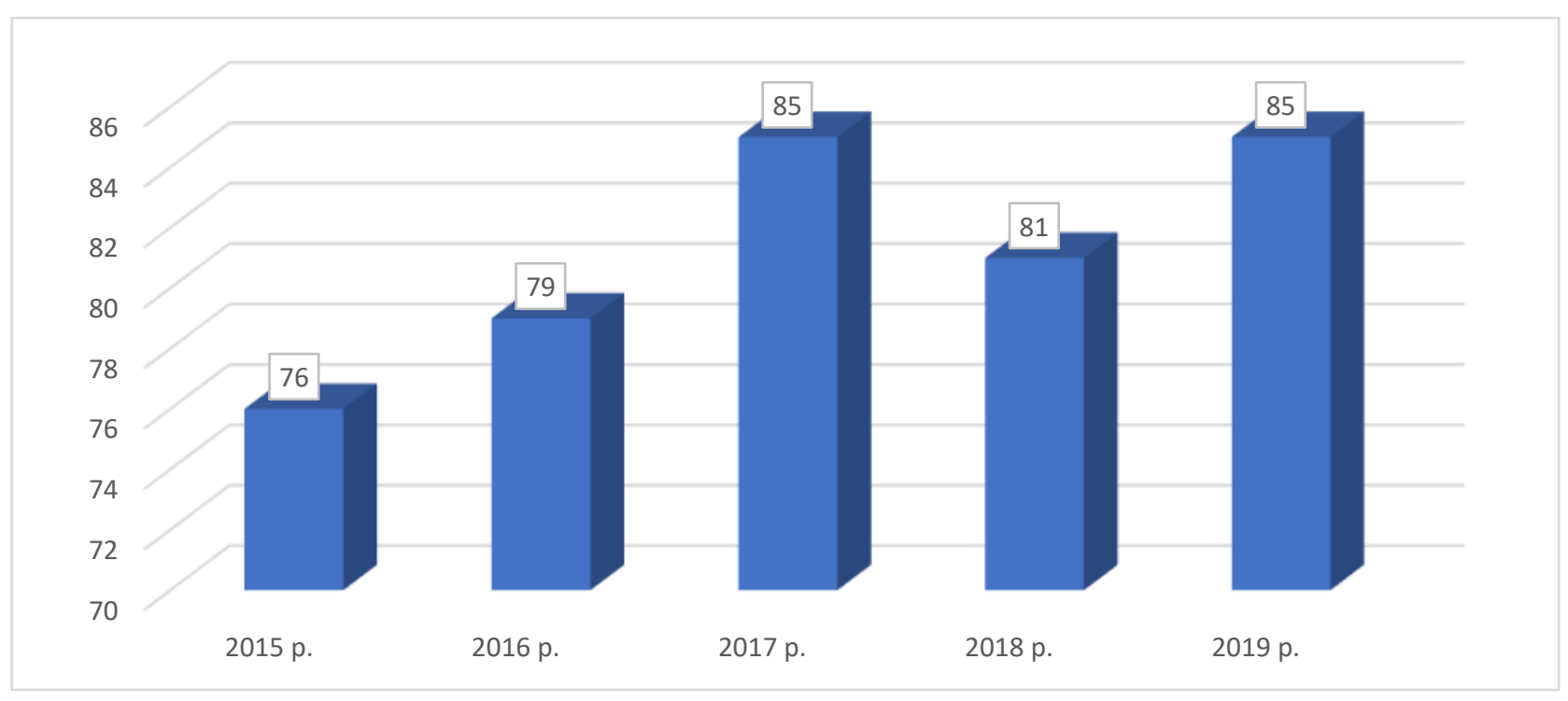

Рис. 3. Позиції України у Global Competitiveness Index

Джерело: [15]

Проведений авторами аналіз рейтингових позицій України за міжнародними рейтинговими індексами про неоднозначність позицій країни у світовому цифровому середовищі. Загалом результати аналізу свідчать про значний цифровий розрив України 3 країнами-сусідами, що свідчить про низький рівень розвитку цифрової економіки.

В Україні наразі дуже швидко впроваджуються інформаційнокомп'ютерні технології в суспільні відносини та діяльність підприємств, що забучує конкурентоздатність вітчизняних підприємств на світових ринках. В табл. 4 наведено рівень розвитку ІКТ в Україні за даними дослідження, що було проведено у 2018 році Міжнародною спілкою електрозв'язку [16].

Таблиия 4

Рівень розвитку інформаційно-комп'ютерних технологій в України

\begin{tabular}{|c|c|c|}
\hline Показник & $2016 \mathrm{p}$. & $2017 \mathrm{p}$ \\
\hline $\begin{array}{l}\text { Число абонентів фіксованого зв'язку на } 100 \\
\text { мешканців }\end{array}$ & 21,6 & 17,2 \\
\hline $\begin{array}{l}\text { Число абонентів мобільного зв'язку на } 100 \\
\text { мешканців }\end{array}$ & 144,0 & 134,0 \\
\hline $\begin{array}{c}\text { Пропускна спроможність зовнішнього шлюзу на } \\
\text { кожного інтернет-користувача }\end{array}$ & 73,4 & 79,91 \\
\hline Частка домогосподарств, які мають комп'ютер & 60,0 & 65,11 \\
\hline $\begin{array}{c}\text { Частка домогосподарств, які мають доступ до } \\
\text { мережі Інтернет }\end{array}$ & 50,2 & 59,8 \\
\hline Частка населення, що використовує Інтернет & 48,9 & 53,0 \\
\hline $\begin{array}{c}\text { Число активних абонентів мобільного ШПД } \\
\text { на } 100 \text { мешканців }\end{array}$ & 8,1 & 10,5 \\
\hline $\begin{array}{c}\text { Число абонентів фіксованого ШПД на } 100 \\
\text { мешканців }\end{array}$ & 11,8 & 12,6 \\
\hline
\end{tabular}

Джерело: [16] 
3 проведеного Міжнародною спілкою електрозв'язку дослідження можна зазначити, що в Україні на 2018 р. спостерігалась позитивна динаміка розвитку інформаційно-комп'ютерних технологій, але вона не досить достатня для загальносвітових значень. На 2021 р. вищезазначеного дослідження не проводилось, але враховуючи значні дії України щодо інтеграції в єдиний європейський цифровий простір, слід чекати позитивної динаміки.

Висновки 3 проведеного дослідження. На основі аналізу чинного законодавчого підгрунтя розвитку цифрової економіки України авторами визначено, що країна поступово робить кроки щодо інтеграції в єдиний європейський цифровий простір, перш за все розробляючи необхідну нормативно-правову базу для забезпечення розвитку цифрової економіки держави. Розроблені нормативно-правові акти, що регламентують розвиток цифрової економіки України, актуалізують необхідність їх уніфікації та консолідації у вигляді Стратегії розвитку цифрової економіки України як стійкого законодавчого підгрунтя для забезпечення стратегічного розвитку цифрової економіки держави. Забезпечення розвитку цифрової економіки України передбачається через періодичне прийняття строкових програмних документів на у формі чинної Концепції розвитку цифрової економіки та суспільства України на 2018-2020 роки. Проведено аналіз рейтингових позицій України за міжнародними рейтинговими індексами: Digital Economy and Society Index; Digital Evolution Index; Digital Adoption Index; ICT Development Index; Global Innovation Index; Networked Readiness Index; e-Intensity; IMD World Digital Competiveness Index; Global Competitiveness Index. Проведено аналіз стану рівня використання та розвитку цифрових технологій в країні.

\section{Перелік посилань}

1. Tapscott, D. The Digital Economy: Promise and Perilin the Age of Networked Intelligence. McGraw-Hill, 1995, 342 p.

2. Подольчак Н. Ю., Білик О. І., Левицька Я. В. Сучасний стан цифровізації в Україні. Електронне фахове наукове видання «Ефективна економіка». № 10. 2019. DOI: 10.32702/2307-2105-2019.10.4. URL: http://www.economy.nayka.com.ua/pdf/10_2019/6.pdf (дата звернення: 10.09.2021).

3. Руденко М. В. Аналіз позицій України в глобальних індексах цифрової економіки. Економіка та держава. № 2. 2021. C. 11-18. DOI: 10.32702/230666806.2021.2.11.

4. Марченко О. Цифрова економіка в Україні: основні тенденції та перспективи розвитку. Galician economik journal. No 4 (65). 2020. C.34-39.

5. Про схвалення Концепції розвитку цифрової економіки та суспільства України на 2018-2020 роки та затвердження плану заходів щодо іiі реалізації: Розпорядження Кабінету Міністрів України від 17 січня 2018 р. № 67-p. URL: https://zakon.rada.gov.ua/laws/show/67-2018-\%D1\%80\#Text (дата звернення: 10.09.2021).

6. Економічна стратегія «Україна $2030 \mathrm{E}$ - країна 3 розвинутою цифровою економікою». Український інститут майбутнього: веб-сайт. URL: 
https://strategy.uifuture.org/kraina-z-rozvinutoyu-cifrovoyu-ekonomikoyu.html (дата звернення: 10.09.2021).

7. Цифрова адженда України - 2020. Концептуальні засади. Першочергові сфери, ініціативи, проекти цифровізації України до 2020 року. HITECH office. $2016 . \quad 90 \quad$ c. https://ucci.org.ua/uploads/files/58e78ee3c3922.pdf. (дата звернення: 12.09.2021).

8. Digital Economy and Society Index (DESI) 2020. Thematic chapters. URL: https://eufordigital.eu/wpcontent/uploads/2020/06/DESI2020Thematicchapters-FullEuropeanAnalysis.pdf (дата звернення: 15.09.2021).

9. The World Bank: Digital Adoption Index. URL: https://www.worldbank.org/en/publication/wdr2016/Digital-Adoption-Index (дата звернення: 15.09.2021).

10. ICT Development Index. "IDI 2017 rank". URL:https://www.itu.int/net4/ITU\$D/idi/2017/ index.html (дата звернення: 15.09.2021).

11. WIPO (2020). World intellectual propertyorganization. URL: https://www.wipo.int/portal/en (дата звернення: 15.09.2021).

12. Рейтинг стран мира по индексу сетевой готовности. URL: https://gtmarket.ru/ratings/networked-readiness-index (дата звернення: 15.09.2021).
13. The 2015
BCG
e-Intensity
Index.
URL:

https://www.bcg.com/publications/interactives/bcg-e-intensity-index

(дата звернення: 15.09.2021).

14. World Competitiveness Center Rankings. URL: https://www.imd.org/centers/world-competitiveness-center/rankings/ (дата звернення: 15.09.2021).

15. The Global Competitiveness Report. Special Edition 2020. URL: https://www3.weforum.org/docs/WEF_TheGlobalCompetitivenessReport2020.pdf (дата звернення: 15.09.2021).

16. Measuring the Information Society Report: Vol. 1 and Vol. 2. Geneva : ITU, 2017. $252 \mathrm{p}$.

\section{References}

1. Tapscott, D. (1995). The Digital Economy: Promise and Perilin the Age of Networked Intelligence. McGraw-Hill, $342 \mathrm{p}$.

2. Podolchak, N. Iu., Bilyk, O. I., Levytska, Ya. V. (2019). The current state of digitalization in Ukraine [Suchasnyi stan tsyfrovizatsii v Ukraini], Electronic professional scientific publication «Effective Economics», No. 10. DOI: 10.32702/2307-2105-2019.10.4, available at: URL: http://www.economy.nayka.com.ua/pdf/10_2019/6.pdf (last accessed 10.09.2021).

3. Rudenko, M. V. (2021). Analysis of Ukraine's position in the global indices of the digital economy [Analiz pozytsii Ukrainy $\mathrm{v}$ hlobalnykh indeksakh tsyfrovoi ekonomiky], Economy and state, No. 2, P. 11-18. DOI: 10.32702/230666806.2021.2.11. 
4. Marchenko, O. (2020). Digital economy in Ukraine: main tendencies and prospects of development [Tsyfrova ekonomika $\mathrm{v}$ Ukraini: osnovni tendentsii ta perspektyvy rozvytku], Galician economik journal, No. 4 (65), P.34-39.

5. On approval of the Concept of development of the digital economy and society of Ukraine for 2018-2020 and approval of the action plan for its implementation: Order of the Cabinet of Ministers of Ukraine of January 17, 2018 № 67-r. [Pro skhvalennia Kontseptsii rozvytku tsyfrovoi ekonomiky ta suspilstva Ukrainy na 2018-2020 roky ta zatverdzhennia planu zakhodiv shchodo yii realizatsii: Rozporiadzhennia Kabinetu Ministriv Ukrainy vid 17 sichnia 2018 r. № 67-r.], available at: https://zakon.rada.gov.ua/laws/show/67-2018-\%D1\%80\#Text (last accessed 10.09.2021).

6. Economic strategy «Ukraine 2030E - a country with a developed digital economy» [Ekonomichna stratehiia «Ukraina 2030E - kraina z rozvynutoiu tsyfrovoiu ekonomikoiu»], Ukrainian Institute of the Future, available at: https://strategy.uifuture.org/kraina-z-rozvinutoyu-cifrovoyu-ekonomikoyu.html (last accessed 10.09.2021).

7. Digital Agenda of Ukraine - 2020. (2016). Conceptual principles. Priority areas, initiatives, projects of digitalization of Ukraine until 2020 [Tsyfrova adzhenda Ukrainy - 2020. Kontseptualni zasady. Pershocherhovi sfery, initsiatyvy, proekty tsyfrovizatsii Ukrainy do 2020 roku], HITECH office, 90 p., available at: https://ucci.org.ua/uploads/files/58e78ee3c3922.pdf. (last accessed 12.09.2021).

8. Digital Economy and Society Index (DESI) 2020. Thematic chapters, available at:

https://eufordigital.eu/wpcontent/uploads/2020/06/DESI2020Thematicchapters-FullEuropeanAnalysis.pdf (last accessed 15.09.2021).

9. The World Bank: Digital Adoption Index, available at: https://www.worldbank.org/en/publication/wdr2016/Digital-Adoption-Index (last accessed 15.09.2021).

10. ICT Development Index. "IDI 2017 rank", available at: URL:https://www.itu.int/net4/ITU\$D/idi/2017/index.html (last accessed 15.09.2021).

11. WIPO (2020). World intellectual property organization, available at: https://www.wipo.int/portal/en (last accessed 15.09.2021).

12. Ranking of the countries of the world according to the Networked Readiness Index [Reyting stran mira po indeksu setevoy gotovnosti], available at: https://gtmarket.ru/ratings/networked-readiness-index (last accessed 15.09.2021).

13. The 2015 BCG e-Intensity Index, available at: https://www.bcg.com/publications/interactives/bcg-e-intensity-index (last accessed 15.09.2021).

14. World Competitiveness Center Rankings, available at: https://www.imd.org/centers/world-competitiveness-center/rankings/ (last accessed 15.09.2021).

15. The Global Competitiveness Report. Special Edition 2020. available at: https://www3.weforum.org/docs/WEF_TheGlobalCompetitivenessReport2020.pdf (last accessed 15.09.2021). 
16. Measuring the Information Society Report (2017). Geneva: ITU, Vol. 1 \& Vol. 2, $252 \mathrm{p}$.

\section{РЕФЕРАТИ РЕФЕРАТЫ ABSTRACTS}

\section{УДК 330.341; JEL Classification: 033 \\ Дмитрієв І.А., Дмитрісва О.І. ОСОБЛИВОСТІ ТА ТЕНДЕНЦІї ЦИФРОВОЇ ЕКОНОМІКИ В УКРАЇ̈І}

Мета. Метою статті $є$ вивчення основних тенденцій розвитку цифрової економіки України та ідентифікація чинного законодавчого підгрунтя. Методика дослідження. В роботі використано методи аналізу та синтезу, системний підхід, порівняльний аналіз. Результати. Характерною ознакою сучасного етапу розвитку економіки $є$ використання цифрових технологій, які стали каталізатором різкого збільшення мобільності товарних та фінансових потоків, забезпечують високу швидкість передачі інформації, внесли значний вклад в глобалізаційні та інтеграційні процеси світової економіки. Інформаційні технології стали невід'ємною частиною суспільних відносин та призвели до появи нових галузей господарства, ринків, конкурентних товарів та послуг. Одним із важливих параметрів, які на світовому рівні визначають якість та ступінь розвитку цифрової економіки, є світові рейтинги. Згідно з Концепцією розвитку цифрової економіки та суспільства України на 2018-2020 основними рейтинговими цілями ії реалізації $\epsilon$ досягнення визначених позицій у рейтингу. Для аналізу особливостей та тенденцій розвитку цифрової економіки України авторами проведено дослідження рейтингових індексів, що дають змогу оцінити іiі стан: Digital Economy and Society Index; Digital Evolution Index; Digital Adoption Index; ICT Development Index; Global Innovation Index; Networked Readiness Index; e-Intensity; IMD World Digital Competiveness Index; Global Competitiveness Index. В дослідженні проведено аналіз стану рівня використання та розвитку цифрових технологій в країні. Наукова новизна: існуючі нормативно-правові акти, що регламентують розвиток цифрової економіки України, актуалізують необхідність їх уніфікації та консолідації у вигляді Стратегії розвитку цифрової економіки України як стійкого законодавчого підгрунтя для забезпечення стратегічного розвитку цифрової економіки держави. Забезпечення розвитку цифрової економіки України передбачається через періодичне прийняття строкових програмних документів на у формі чинної Концепції розвитку цифрової економіки та суспільства України на 2018-2020 роки. Практична значущість: проведений аналіз та визначені особливості та тенденції розвитку цифрової економіки складають інтерес для органів державної влади, до відання яких належить регулювання цифрової економіки; для вітчизняних та зарубіжних науковців, що ведуть дослідження з цього питання.

Ключові слова: цифрова економіка; рейтингові індекси; стимулювання розвитку цифрової економіки; концепції розвитку; потенційний ринок Інтернет. 


\section{УДК 330.341; JEL Classification: 033}

Дмитриев И.А., Дмитриева О.И. ОСОБЕННОСТИ И ТЕНДЕНЦИИ ЦИФРОВОЙ ЭКОНОМИКИ В УКРАИНЕ

Цель. Целью статьи является изучение основных тенденций развития цифровой экономики и идентификация действующей законодательной базы. Методика исследования. В работе использованы методы анализа и синтеза, системный подход, сравнительный анализ. Результаты. Характерной особенностью современного этапа развития экономики является использование цифровых технологий, ставших катализатором резкого увеличения мобильности товарных и финансовых потоков, обеспечивающих высокую скорость передачи информации, внесших значительный вклад в глобализационные и интеграционные процессы мировой экономики. Информационные технологии стали неотъемлемой частью общественных отношений и привели к появлению новых отраслей хозяйства, рынков, конкурентных товаров и услуг. Одним из важных параметров, определяющих на мировом уровне качество и степень развития цифровой экономики, являются мировые рейтинги. Согласно Концепции развития цифровой экономики и общества Украины на 2018-2020, основными рейтинговыми целями ее реализации является достижение определенных позиций в рейтинге. Для анализа особенностей и тенденций развития цифровой экономики Украины авторами проведено исследование рейтинговых индексов, позволяющих оценить ее состояние: Digital Economy and Society Index; Digital Evolution Index; Digital Adoption Index; ICT Development Index; Global Innovation Index; Networked Readiness Index; e-Intensity; IMD World Digital Competiveness Index; Global Competitiveness Index. В исследовании проведен анализ состояния уровня использования и развития цифровых технологий в стране. Научная новизна: существующие нормативно правовые акты, регламентирующие развитие цифровой экономики Украины, актуализируют необходимость их унификации и консолидации в виде Стратегии развития цифровой экономики Украины как устойчивой законодательной основы для обеспечения стратегического развития цифровой экономики государства. Обеспечение развития цифровой экономики Украины предусматривается через периодическое принятие срочных программных документов в форме действующей Концепции развития цифровой экономики и общества Украины на 2018-2020 годы. Практическая значимость: проведенный анализ и выявленные особенности, тенденции развития цифровой экономики представляют интерес для органов государственной власти, к деятельности которых относится регулирование цифровой экономики; для отечественных и зарубежных ученых, ведущих исследования по этому вопросу.

Ключевые слова: цифровая экономика; рейтинговые индексы; стимулирование развития цифровой экономики; концепции развития; потенциальный рынок Интернет. 


\section{UDC 330.341; JEL Classification: 033}

\section{Dmytriiev I.A., Dmytriieva O.I. FEATURES AND TRENDS OF DIGITAL ECONOMY IN UKRAINE}

Purpose. The purpose of the article is to study the main development trends in the digital economy of Ukraine and to identify the current legal basis. Methodology of research. The methods of analysis and synthesis, system approach, comparative analysis were used in the work. Findings. A characteristic feature of the current stage of economic development is the use of digital technologies, which have become a catalyst for a sharp increase in mobility of financial and commodity flows, provide high speed information transfer, have made significant contributions to globalization and integration processes of the world economy. Information technologies have become an integral part of public relations and have led to the emergence of new industries, markets, competitive goods and services. One of the important parameters that determine the quality and degree of development of the digital economy at the global level are world rankings. According to the Concept of development of digital economy and society of Ukraine for 2018-2020 the main rating goals of its realization are reaching certain positions in the rating. To analyze the features and development trends of the digital economy in Ukraine, the authors have studied the rating indices that allow assessing its state: Digital Economy and Society Index; Digital Evolution Index; Digital Adoption Index; ICT Development Index; Global Innovation Index; Networked Readiness Index; e-Intensity; IMD World Digital Competitiveness Index; Global Competitiveness Index. The study analyzes the level of use and development of digital technologies in the country. Originality: The existing regulations governing the development of the digital economy in Ukraine emphasize the need for their unification and consolidation in the form of the Strategy for the development of the digital economy in Ukraine as a stable legal basis for strategic development of the digital economy. It is considered that the development of the digital economy in Ukraine will be provided through the periodic adoption of urgent program documents in the form of the current Concept for the development of the digital economy and society of Ukraine for 2018-2020. Practical value: The analysis which has been made and the identified features and trends of the digital economy are of interest to public authorities responsible for regulating the digital economy; for domestic and foreign scientists conducting research on this issue.

Key words: digital economy; rating indices; stimulation of the digital economy development; development concepts; potential Internet market. 


\section{Відомості про авторів / Сведения об авторах / About the Authors}

Дмитрієв Ілля Андрійович - доктор економічних наук, професор, заслужений діяч науки i техніки України, Харківський національний автомобільно-дорожній університет, проректор з наукової роботи, м. Харків, Україна; e-mail: dmitriev.khnadu@gmail.com; ORCID: https://orcid.org/0000-00018693-3706. Моб. 050-587-97-66.

Дмитриев Илья Андреевич - доктор экономических наук, профессор, заслуженный деятель науки и техники Украины, Харьковский национальный автомобильно-дорожный университет, проректор по научной работе, г. Харьков, Украина.

Dmytriiev Illia - DSci in Economics, Professor, Honored Science and Technology Figure of Ukraine, Kharkov National Automobile and Highway University, Vice-rector for scientific work, Kharkiv, Ukraine.

Дмитрієва Оксана Іллівна - доктор економічних наук, доцент, Харківський національний автомобільно-дорожній університет, завідувачка кафедри економіки i підприємництва, м. Харків, Україна; e-mail: oksanahnadu@gmail.com; ORCID: https://orcid.org/0000-0001-9314-350X. Моб. 063-353-79-98.

Дмитриева Оксана Ильинична - доктор экономических наук, доцент, Харьковский национальный автомобильно-дорожный университет, заведующая кафедры экономики и предпринимательства, г. Харьков, Украина.

Dmytriieva Oksana - DSci in Economics, Associate Professor, Kharkov National Automobile and Highway University, Head of the Department of Economics and Business, Kharkiv, Ukraine. 